\author{
산란계 사료 내 3종류의 Bacillus subtilis의 첨가가 산란후기 계란 품질과 \\ 장내 미생물 및 경골에 미치는 영향 \\ 이완섭 ${ }^{1}$ 이보근 ${ }^{1}$ 김재영 ${ }^{1}$ 김지숙 ${ }^{1}$ 이소연 ${ }^{1}$ 오성택 ${ }^{1}$ 안병기 ${ }^{1}$ 황용배 ${ }^{2}$ 심승규 ${ }^{2}$ 김동건 ${ }^{2}$ 강창원 ${ }^{1 *}$ \\ ${ }^{1}$ 건국대학교 동물생명과학대학, ${ }^{2}$ (주) 제일비이오 연구소 생명공학실
}

\title{
Effects of Three Strains of Bacillus subtilis Supplemented to Diets on Egg Quality, Intestinal Microflora and Tibia in The Late Stage of Laying Hens
}

\author{
Wan Seob Lee ${ }^{1}$, Bo Keun Lee ${ }^{1}$, Jea Young Kim ${ }^{1}$, Ji Sook Kim${ }^{1}$, So Yeon Lee ${ }^{1}$, Sung Taek Oh ${ }^{1}$, Byoung Ki Ahn ${ }^{1}$, \\ Yong Bae Hwang ${ }^{2}$, Seung Kyu $\mathrm{Sim}^{2}$, Dong Gun $\mathrm{Kim}^{2}$ and Chang Won Kang ${ }^{1}$ * \\ ${ }^{1}$ College of Animal Bioscience and Technology, Konkuk University, \\ ${ }^{2}$ Biotechnology Department of CHEILBIO Institute, CHEILBIO Co. Ltd.
}

\begin{abstract}
The objective of this study was to investigate the effects of three strains of Bacillus subtilis (B. subtilis) supplemented to diets on egg production, egg quality, egg yolk cholesterol levels, the profile of cecal microflora, and tibia characteristics in laying hens. One hundred sixty 76-week-old Hy-Line Brown layers were randomly divided into 4 groups with 4 replicates per group (10 birds per replicate). Birds in the control group were fed a corn-soybean meal based diet. The remaining three treated groups were fed the control diet containing either $0.05 \%$ B. subtilis $\mathrm{Ch} 3(\mathrm{~T} 1), 0.05 \%$ B. subtilis $\mathrm{Ch} 3+$ B. subtilis W1 (T2) or $0.05 \%$ B. subtilis commercial product(T3) for 6 weeks, respectively. There were no differences in feed intake, egg weight, egg production and egg mass among the groups. The dietary supplementation of $B$. subtilis improved eggshell strength and Haugh units compared to those of control $(\mathrm{P}<0.05)$. The activities of GOT and GPT in serum were not also affected by the dietary treatments. The population of total microbes and lactic acid bacteria in cecum were significantly increased by the dietary B. subtilis $(\mathrm{P}<0.05)$, but not the coliforms. The cholesterol concentration in egg yolk and serum in the treated groups were significantly decreased compared to those of control $(\mathrm{P}<0.05)$. Also, The levels of phospholipids in serum were significantly decreased compared to those of control $(\mathrm{P}<0.05)$. The supplementation of three strains of $B$. subtilis to diets significantly increased the contents of tibia ash compared to that of control $(\mathrm{P}<0.05)$. Thus, this study showed significant improvements in egg quality, such as eggshell strength and Haugh unit, by dietary B. subtilis strains. The B. subtilis strains added to the diets modulated the profiles of cecal microflora, reflecting beneficial effects in laying hens.
\end{abstract}

(Key words : Bacillus subtilis, Direct-fed microbs, Egg quality, Egg yolk cholesterol, Cecal microflora)

서 론

생균제 (DFM, Direct-fed microbial)는 장 내 균총의 개선을 통 한 영양소 소화율의 증대, 면역기능의 개선 호과(Mohan 등, 1996; Balevi 등, 2001), 근육과 혈액 내 콜레스테롤의 저감(김용 란 등, 2000; Xu 등, 2006) 및 난황 내 콜레스테롤 감소 효과 (Abdulrahim 등, 1996; Haddadin 등, 1996)가 나타남으로서 그 기능성이 활발하게 연구되고 있다.

장 내에서 유익균은 장 표면에 정착하여 병원균을 포함 유해균의 증식을 억제하는 역할을 하며(Jin 등, 1996), 생균제는 유익륜의 균형적인 균수를 유지시킨다(Fuller, 1989; Jin 등, 1997; Sohail
등, 2002). 그 결과 개선된 장 내 환경 내에서 유익균의 활발한 효 소 작용과 미생물에 의해 $\mathrm{Ca}, \mathrm{P}$ 과 같은 무기물과 $\mathrm{N}$ 를 포함한 영 양소 소화 이용률이 개선된다고(Nahashon 등, 1994b) 하였다. 생 균제는 체내 면역 작용에도 영향을 미치는데 혈액 내 백혈구의 분 석 결과 초기 염증시 증가하는 백혈구(white blood cells)와 급만 성 염증시 증가하는 호중구(neutrophil)의 경우 복합 생균제 첨가 급여시 유의하게 낮아 면역 기능에서 매우 긍정적 영향을 미치며 또한 장 내 미생물의 경우 괴사성 장염을 유발하는 clostridium perfringens를 억제하는 효과가 보고되고 있다(우경천 등, 2006). 생균제의 효율을 높이기 위해서는 소화관 내 이동 중 생존성을 높 여 장내 도달시켜 상피세포 및 점막에 정착시키는 것이 중요하다

\footnotetext{
* Corresponding author: Dr. C. W. Kang, College of Animal Bioscience and Technology, Konkuk University, 1 Hwayang-dong, Gwangjin-gu, Seoul 143-701, Korea. Tel: 02-450-3669, Fax: 02-452-9946, E-mail: kkucwkang@empal.com
} 
(박형룡 등, 1994). 따라서 섭취된 생균제는 가축의 위내 $\mathrm{pH}$ 2 4 의 강산에서도 생존하여 소장 내 도달하면 담즙산염(bile salts)에 대한 내성과 반추동물의 경우 미생물에 의한 탄수화물 발효로부터 발생하는 acetic acid, propionic acid, butyric acid 등의 휘발성 지방산에 대한 내성도 필요하다(신형태 등, 2001). 또한 개체에서 기원한 유리한 생균의 선택으로 효율적인 병원성 세균의 억제 효과 능력, 생균제 생산시 공정 및 저장 중에 변형 방지, 면역반응 조절, 긍적적 방향의 미생물 환경 변화 등을 이상적인 생균제의 조건으로 제시하였다(Simmering과 Blaut, 2001).

최근까지 연구 결과를 보면 대부분의 성장기의 육용계나 산란전 기에 이루어졌으며 $\mathrm{Xu}$ 등, 2006; Mutus 등, 2006), 생리적 환경 적 조건하에 생균제의 효과를 제시한 연구는 많지 않다.

본 연구는 국내에서 개발한 2종의 Bacillus subtilis (B. subtilis) 균주와 현재 시판되고 있는 B. subtilis 제품을 이용하여 비교적 생 리적 스트레스가 크다고 판단되는 고온의 여름철에(Mashaly 등, 2004) 산란 후기 산란계를 선텍하여 사료 내 B. subtilis 첨가 급 여가 난 생산성, 난질, 혈액 및 계란 내 콜레스테롤, 장 내 미생물 조성 및 경골 강도와 무기물 중 $\mathrm{Ca}$ 과 $\mathrm{P}$ 의 흡수에 미치는 영향을 조사 평가하였다.

\section{재료 및 방법}

\section{1. 공시동물, 사양관리 및 실험사료}

76주령의 Hy-Line Variety Brown 산란계를 이용하여 동일한 면적의 케이지에 모두 4 개 처리구 4반복, 반복 당 10 수 씩 총 160 수를 선발, 총 6 주간 사양 실험을 실시 하였으며, 공시계는 가로 $\times$ 세로×높이가 각각 $45 \times 62 \times 66 \mathrm{~cm}$ 인 3 단 철제 직립 케이지에 케이 지당 3수 씩 배치하여 사육하였다. 사료 급이기와 니플의 숫자는 반복구별로 동일하게 배치하였다. 사료와 물은 자유채식 및 자유음 수 시켰고, 점등은 $16 \mathrm{~L}: 8 \mathrm{D}$ 로 일정하게 유지하였으며, 기타 사양 관리는 일반적으로 행해지고 있는 국내 사양관리 방법에 준하여 실 시하였다. 옥수수와 대두박 위주의 기초사료는 대사에너지 2,700 $\mathrm{kcal} / \mathrm{kg}$ 와 $15.5 \%$ 의 조단백질 그리고 기타 영양소의 수준은 $\mathrm{NRC}$ 요구량(1994)에 맞추거나 상회하도록 배합하여 대조구 사료로 사 용하였고, 실험사료는 기초사료에 B. subtilis를 첨가하되, $\mathrm{T} 1$ 처리 구에는 B. subtilis $\mathrm{Ch} 3$ 을 $0.05 \%$ 단일 급여 하였고, $\mathrm{T} 2$ 처리구에 는 이미 효과가 검증되어진 B. subtilis W1과 B. subtilis $\mathrm{Ch} 3$ 균 을 $1: 1$ 의 비율로 혼합하여 $0.05 \%, \mathrm{~T} 3$ 처리구에는 일반 시판되고 있는 B. subtilis 제품을 $0.05 \%$ 수준으로 각각 단일 또는 혼합하여 6주간 급여하였다(Table 1).

\section{2. 실험 시료}

본 실험에 사용된 생균제 시료는 제일바이오에서 개발하여 선발 한 2종의 B. subtilis로 $\left[\left(6.4 \times 10^{10} / \mathrm{g}\right)\right.$ B. subtilis Ch3]와 [(6.1×
Table 1. Formula and chemical compositions of the experimental diet

\begin{tabular}{|c|c|}
\hline Ingredients & $\%$ \\
\hline Yellow corn & 59.38 \\
\hline Wheat & 3.00 \\
\hline Wheat bran & 2.00 \\
\hline Rice bran & 2.00 \\
\hline Soybean meal & 15.60 \\
\hline Rapeseed meal & 4.00 \\
\hline Corn gluten meal & 1.80 \\
\hline Tallow & 0.80 \\
\hline MHA $^{1)}, 88 \%$ & 0.10 \\
\hline Choline- $\mathrm{Cl}, 50 \%$ & 0.02 \\
\hline Dicalcium phosphate & 0.20 \\
\hline Limestone & 10.60 \\
\hline $\mathrm{NaCl}$ & 0.20 \\
\hline $\mathrm{NaHCO}_{3}$ & 0.08 \\
\hline Vitamin mixture ${ }^{2)}$ & 0.12 \\
\hline Mineral mixture ${ }^{3)}$ & 0.10 \\
\hline Total & 100.00 \\
\hline \multicolumn{2}{|l|}{ Calculated values } \\
\hline crude protein, $\%$ & 15.50 \\
\hline crude fat, $\%$ & 3.58 \\
\hline crude fiber, $\%$ & 3.10 \\
\hline crude ash, \% & 13.68 \\
\hline $\mathrm{Ca}, \%$ & 4.30 \\
\hline $\mathrm{P}, \%$ & 0.40 \\
\hline Lys, \% & 0.74 \\
\hline Met+Cys, \% & 0.55 \\
\hline TMEn, kcal/kg & 2700 \\
\hline
\end{tabular}

1) Abbreviation: MHA, methionine hydroxy analogue

${ }^{2)}$ Vitamin mixture provided following nutrients per $\mathrm{kg}$ of diet : vitamin A, 10,000 IU; vitamin $\mathrm{D}_{3}, 2,300 \mathrm{IU}$; vitamin E, 20 $\mathrm{IU}$; vitamin $\mathrm{K}_{3}, 2 \mathrm{mg}$; vitamin $\mathrm{B}_{1}, 2 \mathrm{mg}$; vitamin $\mathrm{B}_{2}, 5 \mathrm{mg}$; vitamin $\mathrm{B}_{6}, \quad 3.5 \mathrm{mg}$; vitamin $\mathrm{B}_{12}, \quad 0.02 \mathrm{mg}$; biotin, $0.12 \mathrm{mg}$; niacin, $30 \mathrm{mg}$; pantothenic acid, $10 \mathrm{mg}$; folic acid, $0.7 \mathrm{mg}$.

3) Mineral mixture provided following nutrients per $\mathrm{kg}$ of diet : Fe, $70 \mathrm{mg}$; Zn, $60 \mathrm{mg}$; Mn, $8 \mathrm{mg}$; Cu, $7.5 \mathrm{mg}$; I, $1 \mathrm{mg}$; Se, 0.2 $\mathrm{mg}$; Co, $0.13 \mathrm{mg}$

$\left.10^{10} / \mathrm{g}\right)$ B. subtilis W1] 그리고 일반 시판되고 있는 제품 Bacillus subtilis 종 $\left[\left(1.3 \times 10^{10} / \mathrm{g}\right)\right.$ B. subtilis $\mathrm{CM}$ (commercial product) $]$ 을 실험사료에 단독 및 혼합하여 동일하게 륜일 배합하여 이용하였다. 


\section{3. 조사 항목}

(1) 사료섭취량, 난 생산성과 및 조직 중량

사료섭취량은 매주 마다 급여한 총 양에서 잔량을 제외하여 측정 하였고 실험 기간 동안 매일 오후 2 시에 수집한 정상 산란 개수와 연란, 파란 등을 합한 총 산란 개수를 사육수수로 나누어 산란율을 구하였으며, 수집한 정상란 전부를 칭량하여 정상 계란 수로 나누 어 평균 난중을 산출하였다. 실험 종료 시에 처리구당 반복 별로 2 수씩 총 8 수를 전체 계군의 평균 체중에 유사하게 선발하여 건국 대학교 동물실험윤리위원회(IACUC) 기준에 의거하여 마취 후 도 살시켜 간, 비장 및 복강지방을 채취하여 중량을 측정하였고 생체 중 $100 \mathrm{~g}$ 당 상대적인 중량으로 환산하였다.

\section{(2) 난질 및 난각질}

실험사료를 급여하여 생산된 계란 중 평균치에 해당하는 계란을 2주 간격으로 수집하여 난각 강도, 난각 두께 및 Haugh unit 등 계란의 내부 난질 및 난각질 관련 항목을 측정하였다. 난각 강도는 난각 강도계(FHK 卵殼强度計 富士平 工業株式會社 童 이용하여 계란의 둔단부를 위로하고 수직으로 고정한 후 압력을 가하여 파각 되는 순간의 압력을 측정하였다. 난각 강도 측정 후 난백의 높이를 조사하여 난중을 대비한 Haugh unit 수치를 구하였다 $(\mathrm{QCM}+$, Technical services and suplies, York Ltd., England). 난각 두께 는 계란의 중앙부 난각 파편을 채취하여 난각 후도계(Digimatic micrometer, Series 293-330, Mitutoyo, Japan)를 통해 측정한 두 께의 평균치로 하였다. 난황색은 Roche egg yolk color fan (Roche, Switzerland)과 대조한 색도로서 표시하였다. 난각 색도는 난각 색도계 $(\mathrm{QCM}+$, Technical services and suplies, York Ltd., England)를 이용하여 측정하였다.

\section{(3) 간 기능 관련 효소 활성}

6주간 실험 종료 후 각 반복구 별로 2수씩, 처리당 총 8수씩 선 발한 공시계의 혈핵을 채취한 후 $1,500 \mathrm{rpm}$ 으로 10 분간 원심분리 하여 혈청을 분리하였으며, 혈청 내의 glutamic-oxaloacetic transaminase (GOT) 및 glutamic-pyruvic transaminase (GPT) 활 성은 GOT-GPT kit(GOT-GPT test kit, 아산제약, Korea)를 사 용하여 비색방법으로 측정하였다.

\section{(4) 장내 미생물균총}

혈핵 채취를 위해 처리당 8수씩 선발한 개체들의 맹장 내용물을 phosphate buffer saline (PBS) 용액과 혼합한 이후 homogenizer (T25 ultra-turrax, IKA, Germany)로 균질화 하였고, $10^{-}$부터 $10^{-}$까지 각각의 비율로 희석하였다. Total microbes, Coliforms, lactic acid bacteria 균수를 측정하기 위해 총 세균에는 Plate count agar(Difco, BD science, USA)를, lactic acid bacteria에 는 MRS agar(Difco, BD science, USA)를, Coliforms에는
MacConkey agar(Difco, BD science, USA)를 사용하였고, $37^{\circ} \mathrm{C}$ 에서 36시간 배양 후 균수 측정을 하였다.

(5) 맹장 내 암모니아 농도

맹장 내 암모니아 농도 변화를 알아보기 위해 처리구별 각 개체 의 맹장을 내용물과 함께 적출하여 냉동보관 하였다. 이후 맹장 내 용물 $\lg$ 을 취하여 탈이온수로 $10^{-}$배 희석하여 ammonia assay kit (AA100, Sigma, St. Louis, USA)를 이용하여 측정하였다.

(6) 경골 파쇄강도와 회분함량 및 경골과 혈중 내 $\mathrm{Ca}$, $\mathrm{P}$ 함량

처리구별 개체의 우측 다리의 경골 부분을 적출하여 영하 $20^{\circ} \mathrm{C}$ 에서 보관 후, Instron (Model 4465, Instron Standard Testing Machine, USA)을 이용하여 경골 중심 부위에 압력을 가하여 파 쇄 순간의 최고 압력점을 파쇄강도 수치로 측정하였으며, 측정 단 위는 Newton $(\mathrm{KN})$ 으로 표시하였다. 강도 측정 후 경골 내용물을 $100^{\circ} \mathrm{C}$ 서 24 시간 건조 후 무게를 측정하고, 회화로에서 $600^{\circ} \mathrm{C}$ 24 시간 동안 회화시킨 후 무게를 측정하여 조회분 함량을 조사하 였다. 혈액 내 $\mathrm{Ca}$ 및 $\mathrm{P}$ 함량은 처리당 8수씩 채취한 혈핵을 원심 분리하여 혈청을 분리한 후 $\mathrm{AOAC}$ (1995) 방법에 준하여 유도결 합플라즈마방출분광기(Optima 3300DV, Perkin-elmer Instruments, USA)를 이용하여 측정하였다.

\section{(7) 난황, 간 및 혈액 내 지질 함량}

각각의 처리구에서 공시계의 난황, 혈핵, 간 부위를 채취하여 Folch 등 (1957)의 방법을 응용하여 총 지질을 추출하였다. 이후 추출핵을 microdispenser를 이용하여 silica gel chromarod (CHROMAROD-SIII Mitsubishi Kagaku Iatron, Inc., Japen)에 $1 \mu \ell$ : spot하고 제 1 전개용액(hexane : diethylether : formic acid $=60 \mathrm{ml}: 10 \mathrm{ml}: 0.1 \mathrm{ml}$ )이 들어있는 전개조 내에서 $9 \mathrm{~cm}$ 의 높이까지 1 차 전개시켰고, $60^{\circ} \mathrm{C}$ lry oven에서 2 분간 건조시켰 다. 건조한 이후 제 2 전개용핵 (benzene : hexane $=40 \mathrm{ml}: 40$ $\mathrm{ml}$ )이 들어있는 전개조 내에서 $10 \mathrm{~cm}$ 높이까지 2차 전개시킨 이후 $60^{\circ} \mathrm{C}$ 넌조기에서 다시 2 분간 건조시켰다. 이후 1,2 차 전개를 통해 분리된 각 지질분획은 IATRO SCAN(Mitsubishi Kagaku Iatron Inc., Teijin, Japan)을 이용하여 분석하였다.

\section{4. 통계 분석}

모든 결과에 대한 통계분석은 Statistical Analysis System (SAS Institute, 2002)의 General Linear Model (GLM) Program (one-way ANOVA procedure)을 이용하여 분산분석을 실시하였 고, 분산 분석간의 유의차가 인정되는 경우 Duncan의 다중검정을 이용하여 처리간의 유의성을 검정하였다(Duncan, 1955). 


\section{결과 및 고찰}

\section{1. 사료 섭취량, 난 생산성 및 조직의 상대적 중량}

산란계 사료 내 3종류의 B. subtilis 첨가 급여가 사료섭취량, 난 생산성 및 조직의 상대적 중량에 미치는 영향에 대한 조사 결과를 Table 2에 명시하였다. 전체 실험기간 중의 사료 섭취량은 $122 \mathrm{~g}$ 에 서 $125 \mathrm{~g}$ 으로 각 실험구 간에 비슷한 섭취량을 나타냈다. 산란율은 B. subtilis 첨가한 T2 처리구에서 $69.07 \%$ 로 가장 높았으나 유의 한 변화가 아니었다. 난중 또한 전체 실험 구간에서 근소한 차이로 대조구와 처리구 간에 차이는 나타나지 않았다. 일 산란양은 대조 구 42.51과 비교하여 $\mathrm{T} 1, \mathrm{~T} 2$ 및 $\mathrm{T} 3$ 처리구에서 각각 43.68, $45.91,43.43$ 으로 증가하는 경향을 나타냈지만 유의한 차이는 아 니었다. 뿐만 아니라, 생균제 첨가에 따른 각 장기 조직인 간, 비장 및 복강지방의 체중 당 상대적 중량도 전체 대조구와 처리구 간에 비슷한 중량을 나타냈다.

Sohail 등 (2002)은 상업용으로 개발한(B. subtilis C-3102) Calsporin을 산란 사료 내 첨가 급여 시 난의 생산성, 사료섭취량, 난중 및 체중 변화에 영향을 미치지 않았다고 하였으며, 나재천 등 (2003)은 산란계에 생균제의 첨가 급여가 산란율과 닌중의 증가 경향을 나타냈지만 통계적 유의성은 인정되지 않는다고 하였다. 반 면 Xu 등 (2006)은 산란계 사료 내 B. subtilis $500 \mathrm{ppm}$ 첨가 급 여시 난 생산성, 사료 섭취량, 사료효율이 우수하게 개선되어지나 그 이상으로 첨가 수준을 높인 처리구에서는 개선 효과가 나타나지 않는다고 하였다. 또한 Balevi 등 (2001)은 산란계 사료 내 생균제 $500 \mathrm{ppm}$ 급여시 사료섭취량, 사료효율, 파란율이 개선되었으나 $250 \mathrm{ppm}, 750 \mathrm{ppm}$ 급여 시에는 개선효과가 인정되지 않았다고 하 였다. Xu 등 (2006)의 연구에서 이와 같은 결과는 초과급여 되어 진 미생물 균으로 인한 장 운동성의 증가는 유익한 인자 흡수를 위 한 영양소의 이용성을 바꿀 수 있을 수 있다는 가능성을 제시하였 고 유익균 수의 현저한 증가는 미생물 군 사이에서 공동 생존의 균 형을 파괴시킬 수 있다고 추측하었다. 이처럼 산란계 사료 내 $B$. subtilis의 첨가 급여가 난 생산성에 미치는 영향에 대해서는 상반
된 결과들이 보고되고 있다. 이와 같은 결과의 차이는 급여한 생균 의 종류, 적정 수준의 급여량, 공시계의 주령 및 사양조건 차이에 의한 것으로 판단된다고 하였다(Jin 등, 1998a; Xu 등, 2006). 이 는 주령 및 생균제의 적정 수준에 대한 연구가 고찰되어야 함을 암 시한다.

An 등 (2008)의 연구에서 육계 사료 내 B-glucan과 생균제를 각 각 수준별로 단일 급여한 실험에서 Bacillus amyloliquefaciens 생 균제를 $0.05 \%, 0.1 \%$ 및 $0.2 \%$ 첨가 급여시 처리간에 간, 비장 및 복강지방의 상대적 중량이 변화하지 않았다. Jin 등(1998b)의 연 구에서도 육계 사료 내 Lactobacillus cultures를 $0.1 \%$ 첨가 급여 한 실험에서 간, 비장 및 $\mathrm{F}$ 낭의 상대적 장기의 중량 변화는 나타 나지 않았다고 보고하였다. 이는 생균제의 첨가 급여가 각 장기의 상대적 중량에는 영향을 미치지 않는 결과로 보아 본 실험과 유사 한 결과로 판단된다.

따라서 산란계에 있어서 B. subtilis 첨가는 산란계의 장기조직에 부정적인 영향을 미치지 않는다는 것이 재확인 되었다. 한편 생산 성에 미치는 영향은 생산한계 및 환경 등의 요인에 따라 다르겠으 나 본 실험에서 처럼 산란 후기에는 생산성에 미치는 영향은 크지 않을 것으로 보인다.

\section{2. 계란 품질}

산란계 사료 내 3 종류의 B. subtilis 첨가 급어가 난각 강도, 난 각 두께, 난각색, 난황색 및 Haugh unit에 미치는 영향에 대한 결 과를 Table 3에 명시하었다. 난각 강도는 대조구 $2.40 \mathrm{~kg} / \mathrm{cm}^{2}$ 에 비해 B. subtilis를 첨가한 $\mathrm{T} 1, \mathrm{~T} 2$ 및 $\mathrm{T} 3$ 처리구에서 난각 강도가 각각 $2.58,2.48$ 및 $2.71 \mathrm{~kg} / \mathrm{cm}^{2}$ 으로 특히 $\mathrm{T} 2$ 와 $\mathrm{T} 3$ 처리구에서 유의하게 증가하였으며 $(\mathrm{P}<0.05), \mathrm{T} 3$ 처리구에서도 증가하는 경향 을 나타냈다. 난각 두께 항목에서는 처리간에 큰 차이는 나타나지 않았다. Haugh unit 변화에서는 대조구 81.83 수준에 비해 $B$. subtilis를 첨가한 $\mathrm{T} 1, \mathrm{~T} 2$ 및 $\mathrm{T} 3$ 처리구에서 각각 $87.33,90.06$ 및 86.88의 수준으로 B. subtilis를 첨가한 모든 처리구에서 개선되 었다 $(\mathrm{P}<0.05)$. 한편 난각색은 대조구와 처리구 간에 큰 차이는 없

Table 2. The dietary effect of three strains of $B$. subtilis supplementation on production and relative weight of organs in laying hens ${ }^{1)}$

\begin{tabular}{lrrrr}
\hline & Control & \multicolumn{1}{c}{$\mathrm{T} 1$} & $\mathrm{~T} 2$ & $\mathrm{~T} 3$ \\
\hline \hline Feed intake, g/hen/day & $124.13 \pm 4.00$ & $125.77 \pm 4.85$ & $124.11 \pm 4.21$ & $122.87 \pm 3.93$ \\
Egg production, \% & $64.87 \pm 3.53$ & $64.87 \pm 2.70$ & $69.07 \pm 3.24$ & $64.03 \pm 3.32$ \\
Egg weight, g/egg & $68.11 \pm 0.24$ & $67.34 \pm 0.20$ & $66.79 \pm 0.20$ & $67.63 \pm 0.51$ \\
Daily egg mass & $42.51 \pm 2.64$ & $43.68 \pm 1.82$ & $45.91 \pm 2.20$ & $43.43 \pm 2.32$ \\
Liver, g/100g BW & $2.43 \pm 0.18$ & $2.49 \pm 0.20$ & $2.72 \pm 0.17$ & $2.13 \pm 0.11$ \\
Spleen, g/100g BW & $0.10 \pm 0.01$ & $0.11 \pm 0.02$ & $0.11 \pm 0.01$ & $0.12 \pm 0.01$ \\
Abdominal fat, g/100g BW & $4.39 \pm 0.25$ & $4.07 \pm 0.32$ & $4.75 \pm 0.38$ & $4.54 \pm 0.39$ \\
\hline
\end{tabular}

1) $\mathrm{T} 1,0.05 \%$ B. subtilis $\mathrm{Ch} 3 ; \mathrm{T} 2,0.05 \%$ B. subtilis $\mathrm{Ch} 3+$ B. subtilis $\mathrm{W} 1 ; \mathrm{T} 3,0.05 \%$ B. subtilis $\mathrm{CM}$. 
Table 3. The dietary effect of three strains of $B$. subtilis supplementation on egg qualities in laying hens")

\begin{tabular}{lcccc}
\hline & Control & T1 & T2 & T3 \\
\hline \hline Eggshell strength, $\mathrm{kg} / \mathrm{cm}^{2}$ & $2.40 \pm 0.09^{\mathrm{b}}$ & $2.58 \pm 0.08^{\mathrm{ab}}$ & $2.78 \pm 0.09^{\mathrm{a}}$ & $2.71 \pm 0.10^{\mathrm{a}}$ \\
Eggshell thickness, $\mathrm{mm} / 100$ & $33.44 \pm 0.39$ & $33.47 \pm 0.51$ & $33.60 \pm 0.46$ & $33.43 \pm 0.50$ \\
Eggshell color & $25.02 \pm 1.46$ & $26.27 \pm 0.65$ & $24.91 \pm 0.65$ & $25.81 \pm 0.75$ \\
Yolk color, R.C.F & $6.36 \pm 0.08$ & $6.48 \pm 0.08$ & $6.46 \pm 0.08$ & $6.49 \pm 0.10$ \\
Haugh unit & $81.83 \pm 1.46^{\mathrm{b}}$ & $87.33 \pm 0.93^{\mathrm{a}}$ & $90.06 \pm 1.20^{\mathrm{a}}$ & $86.88 \pm 1.09^{\mathrm{a}}$ \\
\hline
\end{tabular}

${ }^{1)} \mathrm{T} 1,0.05 \%$ B. subtilis Ch3; T2, $0.05 \%$ B. subtilis Ch3 + B. subtilis $\mathrm{W} 1 ; \mathrm{T} 3,0.05 \%$ B. subtilis $\mathrm{CM}$

${ }^{\mathrm{a} b} \mathrm{M}$ Mean \pm SE Values with different superscripts within a row differ significantly $(\mathrm{P}<0.05)$.

었으며 난황색 또한 대조구와 처리구간에 변화를 관찰 할 수 없었다. 산란계를 공시한 연구에서 B. subtilis 급여시 난각 두께, 난황색, Haugh unit가 향상되었다는 결과(Miles 등, 1981; Xu 등, 2006) 등의 개선효과가 나타나는 경우도 있으나 나재천 등 (2003)의 연구 에서는 산란계에 사료 내 복합생균제(Lactobacillus spp., Bacillus spp., Saccharomyces cerevisiae, enterococcus faecallis, phototrophic bacteria) 첨가 급여시 난각 강도와 두께에서 생균제 급여 효과가 나타나지 않았으며, Haugh unit과 난황색도 개선되지 않았 다고 하였다. 반면 Nahashon 등(1994b)과 Xu 등(2006)의 연구 에서는 산란계 사료 내 생균제를 첨가 급여 시 난각 두께가 다소 개선 되었다는 결과 보고가 있다. 이리한 효과는 장 내의 생균제 정착으로 유리한 장내 환경 조성을 통한 더 많은 $\mathrm{Ca}$ 흡수를 도와 생긴 결과라고 하였으며(Xu 등, 2006), Ashmead 등(1985)은 생 균제는 소화관 내 첨가 급여된 미생물 효과로 인해 산란계 혈핵 내 $\mathrm{Ca}, \mathrm{P}$, carotenoid, 그리고 albumin 의 흡수가 개선 되어진다고 하였다. 또한 $\mathrm{Ca}, \mathrm{P}$ 및 salt와 같은 미네랄은 낮은 $\mathrm{pH}$ 에서 더욱 용해되기 쉬우며, 이러한 장내의 산성화 환경은 미네랄 이온화를 촉진시킨다고 하였다. 이는 또한 미네랄 흡수에 필수적인 요소라고 하였다.

본 실험에서는 대조구와 비교하여 모든 B. subtilis 첨가 급여 처 리구에서 난각 강도가 개선되었으며, 그 중에서도 B. subtilis 첨가 급여 처리구 B. subtilis $\mathrm{Ch} 3+$ Bacillus subtilis $\mathrm{W} 1$ 흔합 급여구 와 B. subtilis $\mathrm{CM}$ 급여구에서 높은 개선 효과가 관찰되었다. 또한 각각의 3 종류의 B. subtilis 급여는 Haugh unit를 개선시키는 효 과를 나타냈다. 본 실험은 산란후기의 계군을 대상으로 하였기 때 문에 생산성에는 차이를 보이지 않았지만 난각 및 Haugh unit의 개선효과를 얻을 수 있었던 것으로 보인다. 즉 이 시기에는 이러한 난질 저하가 가장 심하게 나타나는 시기임으로 생리적 활성 기능을
가진 물질이 난질 저하 방지에 효과적임을 보여주고 있다.

\section{3. 혈액 성상}

산란계 사료 내 3 종류의 B. subtilis 첨가 급여가 간 기능 관련 효소인 GOT 및 GPT 변화에 미치는 영향을 Table 4에 명시하였 다. 혈중 GOP 및 GPT 효소의 활성은 대조구와 처리구 모든 실험 구에서 유의한 차이가 나타나지 않았다.

$\mathrm{GOT}$ 및 GPT는 간에서 만들어지는 대사에 필요한 정상 효소로 서 어떤 요인으로 인해 간이 손상 받으면 간세포가 파괴되면서 이 효소가 혈핵으로 유리되어 정상보다 많이 증가하게 된다. 따라서 Lumeij (1997)는 혈중 GOT 및 GPT 효소의 활성 수준은 급여된 사료의 대사 장해 등 손상 정도의 지표로 활용된다고 하였다. 본 실험에서 간 내 GOT 및 GPT 효소 활성 수준은 선행 연구와 비 교할 때 비슷하거나 감소하는 경향(윤지연 등, 2008)을 보임으로 서 각각의 B. subtilis의 첨가 급여에 따라 간 손상에 따른 대사 이 상은 없는 것으로 사료되었다.

이와 같이 간 내 GOT 및 GPT 효소 활성이 대조구 및 처리구 간에 큰 차이가 없는 것이 관찰됨으로써 각각 3 종류의 B. subtilis 첨가 급여가 산란계 내 대사에 부정적인 영향을 미치지 않는다는 것을 시사한다.

\section{4. 장 내의 균총 변화와 암모니아 농도}

산란계 사료 내 3 종류의 B. subtilis 첨가 급여가 장 내의 균총 변화에 미치는 영향과 암모니아 농도에 미치는 영향을 Table 5 에 명시하였다. 장 내 총 균수는 대조구 $6.28 \log \mathrm{cfu} / \mathrm{g}$ 와 비교하여 3 종류의 B. subtilis 균을 첨가 급어한 $\mathrm{T} 1, \mathrm{~T} 2$ 및 $\mathrm{T} 3$ 처리구에서

Table 4. The dietary effect of three strains of $B$. subtilis supplementation on blood profiles in laying hens ${ }^{1), 2)}$

\begin{tabular}{lrrrr}
\hline & \multicolumn{1}{c}{ Control } & \multicolumn{1}{c}{ T1 } & \multicolumn{1}{c}{ T2 } & \multicolumn{1}{c}{ T3 } \\
\hline \hline GOT, IU/L & $179.04 \pm 7.77$ & $184.51 \pm 10.75$ & $201.60 \pm 15.77$ & $165.26 \pm 8.93$ \\
GPT, IU/L & $2.28 \pm 0.19$ & $3.11 \pm 0.45$ & $2.45 \pm 0.21$ & $2.71 \pm 0.28$ \\
\hline
\end{tabular}

${ }^{1)} \mathrm{T} 1,0.05 \%$ B. subtilis Ch3; T2, $0.05 \%$ B. subtilis Ch3 + B. subtilis W1; T3, 0.05\% B. subtilis CM

2) Abbreviation: GOT, glutamic-oxaloacetic transminase; GPT, glutamic-pyruvic transaminase. 
Table 5. The dietary effect of three strains of $B$. subtilis supplementation on intestinal microflora profiles and ammonia concentrations in laying hens ${ }^{1)}$

\begin{tabular}{llccc}
\hline & Control & $\mathrm{T} 1$ & $\mathrm{~T} 2$ & $\mathrm{~T} 3$ \\
\hline \hline Total microbes, $\log \mathrm{cfu} / \mathrm{g}$ & $6.28 \pm 0.11^{\mathrm{c}}$ & $7.06 \pm 0.08^{\mathrm{a}}$ & $7.22 \pm 0.06^{\mathrm{a}}$ & $6.76 \pm 0.08^{\mathrm{b}}$ \\
Lactic acid bacteria, $\log \mathrm{cfu} / \mathrm{g}$ & $7.09 \pm 0.11^{\mathrm{b}}$ & $7.30 \pm 0.06^{\mathrm{ab}}$ & $7.39 \pm 0.06^{\mathrm{a}}$ & $7.34 \pm 0.07^{\mathrm{a}}$ \\
Coliforms, $\log \mathrm{cfu} / \mathrm{g}$ & $5.18 \pm 0.34$ & $4.77 \pm 0.29$ & $5.68 \pm 0.25$ & $5.28 \pm 0.25$ \\
Ammonia concentration, $\mu \mathrm{g} / \mathrm{ml}$ & $2.24 \pm 0.04$ & $2.15 \pm 0.19$ & $1.91 \pm 0.22$ & $2.12 \pm 0.25$ \\
\hline
\end{tabular}

${ }^{1)} \mathrm{T} 1,0.05 \%$ B. subtilis $\mathrm{Ch} 3 ; \mathrm{T} 2,0.05 \%$ B. subtilis $\mathrm{Ch} 3+$ B. subtilis $\mathrm{W} 1 ; \mathrm{T} 3,0.05 \%$ B. subtilis $\mathrm{CM}$

${ }^{\mathrm{a}-\mathrm{c}} \mathrm{Mean} \pm \mathrm{SE}$ Values with different superscripts within a row differ significantly $(\mathrm{P}<0.05)$.

각각 7.06, 7.22 및 $6.76 \log \mathrm{cfu} / \mathrm{g}$ 로 유의하게 증가하였다 $(\mathrm{P}<0.05)$. 또한 B. subtilis 첨가 처리구 중 $\mathrm{T} 1$ 과 $\mathrm{T} 2$ 처리구는 $\mathrm{T} 3$ 처리구와 비교 하여서도 뚜렷하게 증가하였다 $(\mathrm{P}<0.05)$. lactic acid bacteria 균수는 대조구 $7.09 \log \mathrm{cfu} / \mathrm{g}$ 와 비교하여 3종류의 B. subtilis 첨가 급여구 $\mathrm{T} 1, \mathrm{~T} 2$ 및 $\mathrm{T} 3$ 처리구에서 각각 7.30 , 7.39 및 $7.34 \log \mathrm{cfu} / \mathrm{g}$ 로 비슷한 수준을 보이며 개선시켰다 $(\mathrm{P}<0.05)$. 반면, Coliforms 균수는 대조구에 비해 T1, T2 처리구 에서 증가하는 경향이 나타났지만 대조구와 3종류의 B. subtilis 첨 가 급여 처리구 간에 유의한 변화는 아니었다. 장 내 암모니아 농 도는 대조구와 비교하여 3종류의 B. subtilis 처리구에서 감소하였 고, 처리구 중 $\mathrm{T} 2$ 처리구가 가장 낮은 수준이었으나 전체 실험 구 간에서 유의하게 개선시키는 결과는 아니었다.

류경선 등(1999)은 68주령의 산란계에 B. subtilis와 육계와 돼 지의 소장에서 분리한 Lactobacillus salvarius를 각각 $0.1 \%$, $0.2 \%$ 로 수준별로 첨가 급여한 연구에서 장내 혐기성 미생물, 유산 균, 호모균이 대조구와 비교하여 현저하게 증가하였다. 또한 나재 천 등 (2003)은 산란계 사로 내 복합 생균제를 각각 $0.1 \%, 0.2 \%$ 및 $0.4 \%$ 수준으로 첨가 시 맹장 내의 유산균과 혐기성 미생물의 수는 현저하게 증대된다고 보고하였다. 김상호 등(2000)은 25주령 의 산란계 사료 내 유산균(Lactobacillus amylovorus LLA7, Lactobacillus crispatus LLA9, Lactobacillus vaginalis LLA11) 을 각각 단일 및 혼합하여 $10^{7} \mathrm{cfu} / \mathrm{g}$ 을 첨가 급여한 실험에서 맹장 내 유산균을 증가시켰으나, E. coli에는 영항을 미치지 않았다고 하였다. 이는 본 실험에서 사료 내 생균제 첨가시 장 내 lactic acid bacteria 수를 증가시키고 Coliform 균수에 영향을 미치지 않 았다는 보고와 유사한 결과를 나타냈다. 반면, Francis 등(1978), Jin 등(1998b) 및 오종일 등(2007)의 연구에서는 사료 내 생균제 첨가 효과로 대장균의 감소 경향이 나타난다고 하였다. 또한 Jin 등(1998a)의 연구에서도 Lactobacillus를 육계 사료 내 $0.05 \%$, $0.1 \%$ 첨가 시 급여 시 맹장 내 Coliform이 유의하게 감소한다고 하였다. 이는 본 실험이 생균제 첨가 급여 시 Coliform 수가 감소 한다는 연구와 상반된 결과이며 이는 생균제의 종류와 계사 환경변 화 및 체내 생리적 상태 변화에 의한 결과라 할 수 있다. Santoso 등(1999)의 연구에서 Dried Bacillus subtilis Culture(DBSC)를 사료에 첨가 급여 시 산란 계사와 육계사 내 모두 암모니가 가스를
감소 시킨다고 하였다. $\mathrm{DBSC}$ 를 육계 사료 내 $1 \%$ 첨가 급여 시 계분 내의 전체 질소와 요산염태 질소(요산성질소) 및 암모니아태 질소에는 영항을 미치지 않았으나 축적되는 질소를 개선시키며 혈 액 내 요소성 질소의 농도를 감소시킨다고 하였다. 이와 같은 결과 는 장 내 미생물에서 urease을 생성하는 유해 미생물을 억제하여 암모니아 생성 저해 작용으로 인한 결과라고 하였다(Visek, 1978). 하지만 본 실험에서는 장내 암모니아 농도에서 3종류의 $B$. subtilis 첨가 시 유의한 개선 효과는 나타나지 않았다.

따라서 본 실험은 장 내 미생물환경 조성이 3종류의 B. subtilis 첨가 급여 효과로 장 내 Total micrombes와 lactic acid bacteria 의 수준이 긍정적으로 개선되는 것을 관찰 할 수 있었다. 이는 장 내 환경 적응에 비교적 적정한 균의 선택으로 판단된다.

\section{5. 난황, 간 및 혈액의 지질 함량 및 콜레스테롤}

산란계 사로 내 3종류의 B. subtilis 첨가 급여가 난황, 간 및 혈 액의 지질 함량 및 콜레스테롤에 미치는 영향을 Table 6에 명시하 였다. 난황 내의 콜레스테롤 함량은 대조구 $12.93 \mathrm{mg} / \mathrm{g}$ 와 비교하 여 3종류의 B. subtilis 첨가 급여한 $\mathrm{T} 1, \mathrm{~T} 2$ 및 $\mathrm{T} 3$ 처리구에서 각 각 $10.77,11.42$ 및 $10.97 \mathrm{mg} / \mathrm{g}$ 으로 유의하게 감소하였으며 $(\mathrm{P}<0.05)$, 인지질 함량과 중성지방 함량에서는 변화가 나타나지 않 았다. 간 내의 콜레스테롤 함랑은 대조구 $10.66 \mathrm{mg} / \mathrm{g}$ 과 비교하여 $\mathrm{T} 1, \mathrm{~T} 2$ 및 $\mathrm{T} 3$ 처리구는 각각 $8.85,8.33$ 및 $8.29 \mathrm{mg} / \mathrm{g}$ 으로 처리 구 간에 근소한 차이를 나타내며 감소하는 경향이 보였으나 유의성 있는 변화는 아니었으며, 중성지방 함량과 인지질 함량 모두 개선 되지 않았다. 혈액 내의 콜레스테롤 함량은 대조구 156.53 $\mathrm{mg} / 100 \mathrm{ml}$ 과 비교하여 T1 처리구에서 $138.87 \mathrm{mg} / 100 \mathrm{ml}$ 으로 가장 낮은 수준을 나타냈으며 T2 및 T3 처리구에서 각각 147.30 및 $145.02 \mathrm{mg} / 100 \mathrm{ml}$ 으로 개선됨이 관찰되었다 $(\mathrm{P}<0.05)$. 중성지방 함 랑은 대조구와 비교하여 $\mathrm{T} 1$ 과 $\mathrm{T} 3$ 처리구에서 가장 낮은 수준을 나타넸으나 유의한 차이는 아니었다. 인지질의 함량에서는 대조구 $605.24 \mathrm{mg} / 100 \mathrm{ml}$ 와 비교하여 $\mathrm{T} 1, \mathrm{~T} 2$ 및 $\mathrm{T} 3$ 처리구에서 각각 $348.24,409.46$ 및 $378.64 \mathrm{mg} / 100 \mathrm{ml}$ 으로 B. subtilis 첨가 급여구 에서 큰 폭으로 개선시키는 결과가 나타났다 $(\mathrm{P}<0.05)$.

본 실험은 산란계 사료 내에 B. subtilis 첨가 급여 시 난황 및 
Table 6. The dietary effect of three strains of $B$. subtilis supplementation on the lipid composition of egg yolk and liver and serum lipid fractions in laying hens ${ }^{1)}$

\begin{tabular}{|c|c|c|c|c|}
\hline & Control & $\mathrm{T} 1$ & $\mathrm{~T} 2$ & $\mathrm{~T} 3$ \\
\hline Egg yolk & \multicolumn{2}{|c|}{ " } & \multicolumn{2}{|c|}{ 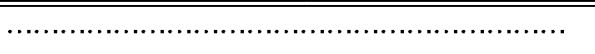 } \\
\hline Cholesterol & $12.93 \pm 0.83^{\mathrm{a}}$ & $10.77 \pm 0.24^{\mathrm{b}}$ & $11.42 \pm 0.27^{\mathrm{b}}$ & $10.97 \pm 0.24^{\mathrm{b}}$ \\
\hline Triacylglycerol & $234.13 \pm 12.08$ & $230.61 \pm 14.19$ & $241.70 \pm 13.17$ & $211.47 \pm 17.17$ \\
\hline Phospholipid & $143.86 \pm 10.56$ & $128.39 \pm 9.16$ & $134.81 \pm 8.51$ & $129.56 \pm 10.96$ \\
\hline \multicolumn{5}{|l|}{ Liver } \\
\hline Cholesterol & $10.66 \pm 1.05$ & $8.85 \pm 0.81$ & $8.33 \pm 0.49$ & $8.29 \pm 0.79$ \\
\hline Triacylglycerol & $56.44 \pm 13.28$ & $41.97 \pm 11.18$ & $53.63 \pm 9.82$ & $27.37 \pm 12.45$ \\
\hline Phospholipid & $23.51 \pm 0.91$ & $25.62 \pm 1.02$ & $23.56 \pm 0.86$ & $24.15 \pm 1.09$ \\
\hline Serum & \multicolumn{2}{|c|}{ 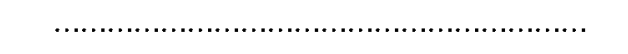 } & (....................... & ....................... \\
\hline Cholesterol & $156.53 \pm 4.68^{\mathrm{a}}$ & $138.87 \pm \quad 4.42^{\mathrm{b}}$ & $147.30 \pm 1.93^{\mathrm{b}}$ & $145.02 \pm 2.76^{\mathrm{b}}$ \\
\hline Triacylglycerol & $1199.38 \pm 228.10$ & $841.95 \pm 203.86$ & $1102.86 \pm 192.26$ & $896.90 \pm 100.45$ \\
\hline Phospholipid & $605.24 \pm 74.13^{\mathrm{a}}$ & $348.24 \pm 47.27^{\mathrm{b}}$ & $409.46 \pm 41.37^{\mathrm{ab}}$ & $378.64 \pm 27.48^{\mathrm{b}}$ \\
\hline
\end{tabular}

${ }^{1)} \mathrm{T} 1,0.05 \%$ B. subtilis Ch3; T2, $0.05 \%$ B. subtilis $\mathrm{Ch} 3+$ B. subtilis $\mathrm{W} 1$; T3, $0.05 \%$ B. subtilis $\mathrm{CM}$

${ }^{\mathrm{a} b}$ Mean \pm SE Values with different superscripts within a row differ significantly $(\mathrm{P}<0.05)$.

혈액 내 콜레스테롤 농도가 감소하였다는 연구(Mohan 등, 1995; Haddadin 등, 1996; Xu 등, 2006)와 육계 사료 내 생균제 첨가 급여 시 혈액 내 콜레스테롤 감소(김용란 등, 2000)와 일치하는 실험 결과를 나타냈다. 이는 생군제 내에 일부 미생물의 활성에 의 해 소화관 내에서 스스로 세포대사를 위해 콜례스테롤을 소화하여 재 흡수되는 콜레스테롤을 감소시켜 일어난 결과라고 하였다 (Nelson과 Gilliland, 1984). 또한 Kalavathy 등(2003)은 lactic acid bacterial 균이 체내에 장간 순환을 변화시키며, 장 내에서 미 생물 세포의 작용과 담즙산염 가수분해효소 활성으로 섭취된 콜레 스테롤의 이용이 증가함으로써 난황 및 혈액 내의 콜레스테롤 합성 이 줄어든다고 보고하였다. 이는 본 실험 lactic acid bacterial 균 이 증가하였다는 결과와 난황 및 혈액 내의 콜레스테롤 합성이 감
소하였다는 결과와 일치하는 부분이다. 따라서 최근 계란 내 콜레 스테롤 함량이 높다는 이유로 계란 소비에 부정적인 영향을 끼쳐온 점을 감안할 때 사료를 통한 $B$. subtilis 첨가로 저 콜레스테롤 계 란을 생산한다면 계란 함유 식품 소비를 통한 계란 소비 증진을 기 대할 수 있을 것으로 보인다.

6. 경골 파쇄강도, 무기질 조성 및 혈액 내 $\mathrm{Ca}, \mathrm{P}$ 함량

산란계 사료 내 3 종류의 B. subtilis의 첨가 급여가 경골의 파쇄 강도, 회분 함량, $\mathrm{Ca}$ 과 $\mathrm{P}$ 함량에 미치는 영향 및 혈핵 내 $\mathrm{Ca}, \mathrm{P}$ 함량에 미치는 영향을 Table 7에 명시하였다. 경골 파쇄강도는 유 사한 강도 수준을 나타냈다. 반면, 회분 함량은 $\mathrm{T} 3$ 처리구에서 다

Table 7. The dietary effect of three strains of $B$. subtilis supplementation on physical characteristics and chemical compositions of tibia and serum in laying hens ${ }^{1)}$

\begin{tabular}{|c|c|c|c|c|}
\hline & Control & $\mathrm{T} 1$ & $\mathrm{~T} 2$ & $\mathrm{~T} 3$ \\
\hline Tibia breaking strength, $\mathrm{KN}$ & $0.23 \pm 0.01$ & $0.24 \pm 0.01$ & $0.25 \pm 0.01$ & $0.24 \pm 0.01$ \\
\hline Ash, $\%$ & $38.32 \pm 0.95^{\mathrm{b}}$ & $42.36 \pm 0.92^{\mathrm{a}}$ & $42.28 \pm 0.27^{\mathrm{a}}$ & $41.98 \pm 0.85^{\mathrm{a}}$ \\
\hline \multicolumn{5}{|l|}{ Tibia } \\
\hline $\mathrm{Ca}, \%$ & $38.69 \pm 0.43$ & $38.85 \pm 0.59$ & $39.65 \pm 0.42$ & $38.84 \pm 0.11$ \\
\hline $\mathrm{P}, \%$ & $16.74 \pm 0.13$ & $16.55 \pm 0.10$ & $16.69 \pm 0.09$ & $16.70 \pm 0.34$ \\
\hline \multicolumn{5}{|l|}{ Serum } \\
\hline $\mathrm{Ca}, m g / d L$ & $23.74 \pm 1.13$ & $26.16 \pm 1.18$ & $24.41 \pm 0.96$ & $26.10 \pm 2.10$ \\
\hline $\mathrm{P}, m g / d L$ & $5.89 \pm 0.30$ & $6.34 \pm 0.56$ & $5.55 \pm 0.23$ & $6.26 \pm 0.55$ \\
\hline
\end{tabular}

\footnotetext{
${ }^{1)} \mathrm{T} 1,0.05 \%$ B. subtilis $\mathrm{Ch} 3 ; \mathrm{T} 2,0.05 \%$ B. subtilis $\mathrm{Ch} 3+$ B. subtilis $\mathrm{W} 1 ; \mathrm{T} 3,0.05 \%$ B. subtilis $\mathrm{CM}$
}

${ }^{\mathrm{a} b \mathrm{~b}}$ Mean \pm SE Values with different superscripts within a row differ significantly $(\mathrm{P}<0.05)$. 
른 처리구에 비해 다소 감소하는 경향이 나타났지만, 대조구 $38.32 \%$ 에 비해 각각의 B. subtilis 첨가 급여구 $\mathrm{T} 1, \mathrm{~T} 2$ 및 $\mathrm{T} 3$ 처 리구에서 각각 $42.36,42.28$ 및 $41.98 \%$ 로 개선시켰다 $(\mathrm{P}<0.05)$. 경골 내 $\mathrm{Ca}$ 함량은 $\mathrm{T} 2$ 처리구에서 $39.65 \%$ 로 실험구 중에서 가장 높은 함량을 나타냈지만 모든 실험구에서 유의한 차이를 관찰 할 수 없었다. 경골 내 $\mathrm{P}$ 함량 역시 대조구과 처리구 모두 $16.55 \%$ 에 서 $16.74 \%$ 범위 이내의 함량이 나타났다. 혈액 내의 $\mathrm{Ca}$ 함량은 대조구의 $23.74 \mathrm{mg} / \mathrm{dL}$ 과 비교하여 B. subtilis 첨가 급여구인 $\mathrm{T} 1$ 및 T3에서 각각 26.16 및 $26.10 \mathrm{mg} / \mathrm{dL}$ 으로 높은 함량을 나타냈지 만 유의한 변화는 아니었다. $\mathrm{P}$ 함량 또한 $\mathrm{Ca}$ 함량과 비슷한 경향 이 관찰되었다.

Nahashon 등 (1996)은 산란기간 동안 Lactobacillus를 첨가 급 여시 질소와 칼슘의 축적률이 증가한다고 하였다. 또한 Lactobacillus를 첨가 급여 시 $\mathrm{Ca}$ 과 질소의 축적률을 개선시킨다 고 하였으며(Nahashon 등, 1994b; Nahashon 등, 1994c; Nahashon 등, 1996) 이와 같은 칼슘 축적률의 증가는 Lactobacillus의 첨가 급여가 위장 내의 $\mathrm{pH}$ 감소를 일으켜 (Ashmead 등, 1985; Nahashon 등, 1994a) 나타난 결과로 사료된 다고 하였다(Nahashon 등, 1996). Angel 등(2005)의 연구에서는 육계 사료 내 각각 단백질, $\mathrm{Ca}$ 및 $\mathrm{P}$ 의 함량을 수준별로 감소시켜 급여한 실험에서 영양소 수준이 감소함에 따라 $\mathrm{DFM}$ 을 첨가했을 때 단백질, $\mathrm{Ca}$ 및 $\mathrm{P}$ 의 이용률은 개선된다고 보고하였다. 또한 Mutus 등(2006)의 연구에서는 육계 사료 내 $500 \mathrm{ppm}$ 의 생균제 급여 시 빼의 무게, 길이, 골간지름 및 $\mathrm{Ca}$ 함량 등의 유의한 변화 를 관찰 할 수 없었지만, $\mathrm{P}$ 의 함량과 회분 함량이 증가하였으며 경 골의 강도와 탄성이 다소 증가하였다는 연구 결과가 보고되고 있 다. 이는 본 실험과 경골 내 회분 함량이 증가하였다는 결과와 일 부 일치하며 이와 같은 결과는 생균제의 첨가 급여가 빼의 광물질 함유 정도와 빼의 성장을 증가시킬 가능성이 시사된다. 또한 Nahashon 등(1996)는 Lactobacillus 첨가 급여는 $\mathrm{Ca}$ 과 $\mathrm{P}$ 의 축 적, 사료섭취량, 난의 크기와 명확한 관계가 성립한다고 하였다. 경 골 내에서 회분의 비율과 $\mathrm{P}$ 의 함량은 상관관계를 이루며 함께 증 가하며 증가된 회분의 비율은 또한 빼의 강도와도 연관이 있으며 이는 뼈의 광물질 흡수를 개선시킨 결과라고 하였다(Mutus 등, 2006). 이와 같이 사로 내 생균제의 첨가 급여는 $\mathrm{Ca}, \mathrm{P}$ 과 같은 무 기물 영양소 이용률 개선 가능성을 제시 하였으며 각각의 상관관계 가 성립한다고 하였다.

본 실험의 결과 각각의 B. subtilis 균주가 경골 내 회분의 함량 을 증가시키는 호과가 관찰되었지만 회분과 뼈의 강도와의 상관관 계 및 $\mathrm{P}$ 의 함량과의 상관 관계가 성립하지 않았다. 이는 난 생산성 에도 영향을 미치지 않는 것으로 미루어 보아 난 생산성과 $\mathrm{Ca}$ 와 $\mathrm{P}$ 의 축적에 미치는 영향이 다소 미흡한 것으로 사료된다. 하지만 경 골 내 회분 함량의 증가는 $\mathrm{Ca}$ 과 $\mathrm{P}$ 의 체내 대사에 영항을 미칠 가 능성이 제시된다. 특히 산란후기에 발생 빈도가 높은 케이지 피로 증후군과 같은 대사성 질병 예방을 위해서도 사료 내 B. subtilis와 같은 첨가제의 사용이 권장되고 있는데 다만 이러한 대사성 질병
은 산란 초기부터 서서히 진행되는 대사 장애인 관계로 더욱 장기 적인 실험과 $\mathrm{Ca}$ 과 $\mathrm{P}$ 이 체내 대사 축적에 대한 확고한 연구가 이루 어질 때 결론에 도달할 수 있을 것으로 보인다.

\section{요 약}

본 연구는 3 종류의 B. subtilis 균주를 이용하여 제조한 생균제를 산란계 사료에 급여시 난 생산성, 난질, 난황 내 콜레스테롤, 장 내 미생물 조성 및 경골 내 성상에 미치는 영향을 조사하였다. 76주령 의 Hy-Line Variety Brown 산란계 160수를 공시하여 모두 4개 처리구에 4반복(반복당 10수)로 임의배치 후 6주간의 사양실험을 실시하였다. 산란계용 사료는 옥수수 대두박을 기초로 하여 대사 에너지 $2,700 \mathrm{kcal} / \mathrm{kg}$ 와 조단백질 $15.5 \%$ 인 일반 사료 급여구를 대 조구로 하였으며, (T1) 처리구에는 B. subtilis Ch3을 $0.05 \%$, (T2) 처리구에는 B. subtilis $\mathrm{Ch} 3+$ B. subtilis $\mathrm{W} 1$ 혼합제제를 $0.05 \%$, (T3) 처리구에는 시판되고 있는 B. subtilis 제품을 $0.05 \%$ 수준으로 대조구 사료에 각각 혼합하여 급여하였다. 실험기간 동안 의 난 생산성, 수당 사료섭춰량, 난중 및 일 산란량 모두 변화가 나타나지 않았다. 난각 강도와 Haugh unit에서는 대조구와 비교하 여 처리구에서 개선되었으며 $(\mathrm{P}<0.05)$, 간 내 GOT 및 GPT 효소 는 처리구 간에 변화가 관찰되지 않았다. 맹장 내 총 균수와 lactic acid bacteria의 균수가 대조구와 비교하여 처리구에서 유의하게 개선되었다 $(\mathrm{P}<0.05)$. 하지만 Coliforms 균수는 처리 간에 변화가 나타나지 않았다. 난황과 혈액 내 콜레스테롤 농도는 대조구와 비 교하여 처리구에서 감소하였다 $(\mathrm{P}<0.05)$. 또한 혈액 내 인지질도 대조구에 비교하여 처리구에서 감소하는 경향이 나타났다 $(\mathrm{P}<0.05)$. 경골 퐈쇄강도는 처리간에 차이가 없었으나, 경골 내 회분 함량은 대조구와 비교하여 모든 실험구에서 개선시키는 결과가 관찰되었다 $(\mathrm{P}<0.05)$. 따라서 본 실험은 산란후기 사로 내 각각의 B. subtilis 균주를 첨가 급여 하였을 때 난각 강도와 Haugh unit를 개선시키 는 효과가 관찰되었고 장내의 총 균수와 유산균 수를 증가시킴으로 써 유리한 장 내 환경으로 개선시켰으며 또한 난황과 혈액 내 콜레 스테롤을 감소시키는 효과가 나타났다. 또한 각각 3 종류의 $B$. subtilis 첨가 급여 효과로 경골 내 회분 함량을 증가시킨 결과로 보아 $\mathrm{Ca}$ 과 $\mathrm{P}$ 과 같은 무기질 영양소의 체내 대사 이용률이 개선될 가능성이 시사되었다. 이와 같은 측면에 접근하여 B. subtilis의 수 준별 첨가로 인한 혈액 및 경골의 $\mathrm{Ca}$ 과 $\mathrm{P}$ 의 축적률 변화와 사료 내 하향 수준의 무기질 공급 등의 추후 연구조사가 이뤄져야 할 가 치가 있다고 판단된다.

(색인어: 바실러스 서브틸리스, 생균제, 계란품질, 난황 콜레스테롤, 장내 미생물)

\section{인 용 문 헌}

Abdulrahim, S. M., Haddadin, S. Y., Hashlamoun, E. A. and Robinson, R. K. 1996. The influence of Lactobacillus acidophilus 
and bacitracin on layer performance of chickens and cholesterol content of plasma and egg yolk. Br. Poult. Sci. 37:341-346.

An, B. K., Chang, H. I., Kim, S. W., Yun, C. W. and Kang, C. W. 2008. Growth performance and antibody response of broiler chicks fed yeast derived B-glucan and single-strain probiotics. Asian-Aus. J. Anim. Sci. 21:1027-1032.

Angel, R., Dalloul, R. A. and Doerr, J. 2005. Performance of Broiler Chickens Fed Diets Supplemented with a Driect-Fed Microbial. Poult. Sci. 84:1222-1231.

A.O.A.C. 1995. Official method of analysis 16th ed. Association of Official Analytical Chemists, Washington, D. C.

Ashmead, H. D., Graff, D. J. and Ashmead, H. H. 1985. Intestinal absorption of metal ions and chelates. Charles C. Thomas Publishers, Springfield, IL.

Balevi, T., Uçan, U. S., Coun, B., Kurtou, V. and Çetingül, S. 2001. Effect of dietary probiotic on performance and humoral immune response in layer hens. Br. Poult. Sci. 42:456-461.

Duncan, D. B. 1955. Multiple range and Multiple F test. Biometr. 11:1-42.

Folch, J., Lee, M. and Sloane-Stanley, G. H. 1957. A simple method for the isolation and purification of total lipids from animal tissue. J. Biol. Chem. 226:497-509.

Francis, C., Janky, D. M., Arafa, A. S. and Harms, R. H. 1978. Interrelationship of Lactobacillus and zinc bacitracin in the diets of turkey poults. Poult. Sci. 57:1687-1689.

Fuller, R. 1989. Probiotics in man and animals. Appl. Bacteriol. J. 66:365-368.

Haddadin, M. S., Abdulrahim, S. M., Hashlamoun, E. A. and Robinson, R. K. 1996. The effect of Lactobacillus acidophilus on the production and chemical composition of hen's eggs. Poult. Sci. 75:491-494.

Jin, L. Z., Ho, Y. W., Abdullah, N. and Jalaludin, S. 1996. Influence of dried Bacillus subtilis and Lactobacilli cultures on intestinal microflora and performance in broilers. Asian-Australas J. Anim. Sci. 9:397-403.

Jin, L. Z., Ho, Y. W., Abdullah, N. andJalaudin, S. 1997. Probiotics in poultry: modes of action. J. World's Poult. Sci. 53:351-368.

Jin, L. Z., Ho, Y. W., Abdullah, N. andJalaudin, S. 1998a. Growth performance, intestinal microbial populations, and serum cholesterol of broilers fed diets containing Lactobacillus cultures. Poult. Sci. 77:1259-1265.

Jin, L. Z., Ho, Y. W., Abdullah, N., Ali, M. A. and Jalaludin, S. 1998b. Effects of adherent Lactobacillus cultures on growth, weight of organs and intestinal microflora and volatile fatty acids in broilers. Anim. Feed Sci. Tech. 70:197-209.

Kalavathy, R., Abdullah, N., Jalaludin, S. and Ho, Y. W. 2003.
Effects of Lactobacillus cultures on growth performance, abdominal fat deposition, serum lipids and weight of organs of broiler chickens. Br. Poult. Sci. 44:139-144.

Lumeij, J. T. 1997. Avian Clinical Biochemistry. In: Clinical Biochemistry of Domestic Animals (ed. J. J. Kanebo, J. W. Harvey, and M. L. Bruss, 5th) Academic Press. 857-883.

Mashaly, M. M., HendricksIII, 2 G. L., Kalama, M. A., Gehad, A. E., Abbas, A. O. and Patterson, P. H. 2004. Effect of Heat Stress on Production Parameters and Immune Responses of Commercial Laying Hens. Poult. Sci. 83:889-894.

Miles, R. D., Arafa, A. S. and Harms, R. H. 1981. Effects of a living nonfreeze dried Lactobacillus acidophilus culture on performance, egg quality and gut microflora in commercial layers. Poult. Sci. 60:993-1004.

Mohan, B., Kadirvel, R., Bhaskaran, M. and Natarajan, A. 1995. Effect of probiotic supplementation on serum/yolk cholesterol and on egg shell thickness in layers. Br. Poult. Sci. 36:799-803.

Mohan, B., Kadirvel, R., Natarajan, A. and Bhaskaran, M. 1996. Effect of probiotic supplementation on growth, nitrogen utilisation and serum cholesterol in broilers. Br. Poult. Sci. 37:395-401.

Mutus, R., Kocabagli, N., Alp, M., Acar, N., Eren, M. and Gezen, S. S. 2006. The Effect of Dietary Probiotic Supplementation on Tibial Bone Characteristics and Strength in Broilers. Poult. Sci. 85:1621-1625.

Nahashon, S. N., Nakaue, H. S. and Mirosh, L. W. 1994a. Phytase activity, phosphorus and calcium retention, and performance of Single Comb White Leghorn layers fed diets containing two levels of available phosphorus and supplemented with direct-fed microbials. Poult. Sci. 73:1552-1562.

Nahashon, S. N., Nakaue, H. S. and Mirosh, L. W. $1994 \mathrm{~b}$. Production variables and nutrient retention in Single Comb White Leghorn laying pullets fed diets supplemented with direct-fed microbials. Poult. Sci. 73:1699-1711.

Nahashon, S. N., Nakaue, H. S., Snyder, S. P. and Mirosh, L. W. 1994c. Performance of Single Comb White Leghorn layers fed corn-soybean meal and barley-corn-soybean meal diets supplemented with a direct-fed microbial. Poult. Sci. 73:1712-1723.

Nahashon, S. N., Nakaue, H. S. and Mirosh, L. W. 1996. Performance of Single Comb White Leghorn fed a diet supplemented with a live microbial during the growth and egg laying phases. Anim. Feed. Sci. Tech. 57:25-38.

Nelson, C. R. and Gilliland, S. E. 1984. Cholesterol uptake by Lactobacillus acidophilus. J. Dairy Sci. 67:(Suppl. 1). Abstr.

NRC, 1994. Nutrient requirements of poultry. 9th ed. National Academy Press. Washington D. C. Nahashon S. N., Nakaue H. 
S., Mirosh L. W.

Santoso, U., Ohtani, S., Tanaka, K. and Sakaida, M. 1999. Dried Bacillus subtilis culture reduced ammonia gas release in poultry house. Asian-Aust. J. Anim. Sci. 12:806-809.

SAS. 2002. SAS User's guide. Statistics, Version 8. e., SAS Institute. Inc. Cary, NC.

Simmering, R. and Blaut M. 2001. Pro-biotics and prebiotics - the tasty guardian angels. Appl. Microbiol. Biotechnol. 55:19-28.

Sohail, S. S., Bryant, M. M., Voitle, R. A. and Roland, D. A. 2002. Influence of calsporin on commercial leghorns. J. Appl. Poult. Res. 11:379-387.

Visek, W. J. 1978. The Mode of Growth Promotion by Antibiotics. J. Anim. Sci. 46:1447-1469.

Xu, C. L., Ji, C., Ma, Q., Hao, K., Jin, Z. Y. and Li, K. 2006. Effects of a dried Bacillus subtilis culture on egg quality. Poult. Sci. 85:364-368.

김상호, 박수영, 유동조, 이상진, 강보석, 최철환, 류경선, 2000. 유산균의 첨가 급여가 산란 생산성, 소화기관 미생물 변화 및 계란 품질에 미치 는 영향. 한국가금학회지. 27:235-242.

김용란, 안병기, 김문수, 강창원. 2000. 생균제의 사료내 첨가가 육계성적과 혈중 콜레스테롤, 소장 크기 및 장내 균총에 미치는 영향. 한국동물자 원과학회지. 42:849-858.
나재천, 김태호, 서옥석, 유동조, 김학규, 이상진, 김상호, 하정기, 김재황. 2003. 복합생균제의 급여가 산란계의 생산성에 미치는 영향. 한국가금 학회지. 30:145-150.

류경선, 박홍석, 류명선, 박수영, 김상호, 송희종. 1999. 생균제의 급여가 산란계의 생산성과 장내 미생물의 변화에 미치는 영향. 동물자원과학 회지. 26:253-259.

박형룡, 한인규, 허기남. 1994. Yeast culture의 첨가가 육계의 생산성과 장내 yeast colony에 미치는 영향. 한국영양사료학회지. 18:346.

신형태, 금동혁, 이향우, 이동권, 황보식, 이재흥. 2001. 생균제 개발을 위 한 새로운 호모균의 선별. 한국가금학회지. 43:721-726.

오종일, 김귀만, 고석영, 배인휴, 이상석, 양철주. 2007. 민들레와 생균제의 첨가가 육계의 성장 및 체조성에 미치는 영향. 한국가금학회지. 34:319-327.

우경친, 정병윤, 이문구, 백인기. 2006. Beta-Glucan과 MOS의 복합제 (Safmannan)와 복합생균제가 육계의 생산성과 영양소 이용율, 소장내 미생물 균총 및 면역체계에 미치는 영향. 한국가금학회지. 33:151-158. 윤지연, 김재영, 김지숙, 이보근, 안병기, 황용배, 강성기, 김동건, 강창원. 2008. 생균제 및 Colistin ${ }^{\circledR}$ 복합 첨가제의 급여가 산란계의 생산성과 계란의 품질에 미치는 영향. 한국가금학회지. 35:153-162.

(접수일자 : 2010. 2. 17 / 수정일자 : 2010. 6.14/

채택일자 : 2010. 9. 13) 